\title{
DOI https://doi.org/10.30525/978-9934-26-044-5-27
}

\section{ВИВЧЕННЯ МОТИВІВ ДО ЗАНЯТЬ СПОРТИВНИМИ ІГРАМИ У ВІЙСЬКОВОСЛУЖБОВЦІВ ІЗ НАСЛІДКАМИ БОЙОВОЇ ТРАВМИ}

\author{
Юденко О. В. \\ кандидат педагогічних наук, \\ доцент кафедри професійного, неолімпійського \\ та адаптивного спорту \\ Національний університет фізичного виховання і спорту України \\ м. Київ, Украӥна \\ Білошицький В. В. \\ підполковник, \\ начальник науково-дослідної лабораторії наукового супроводження \\ розроблення нормативів і стандартів фізичної підготовки і спорту \\ Навчально-науковий інститут фізичної культури \\ та спортивно-оздоровчих технологій \\ Національного університету оборони України \\ імені Івана Черняховського \\ м. Київ, Украӥна \\ Петрачков О. В. \\ кандидат педагогічних наук, доцент, \\ полковник, начальник \\ Навчально-науковий інститут фізичної культури \\ та спортивно-оздоровчих технологій \\ Національного університету оборони України \\ імені Івана Черняховського \\ м. Київ, Україна
}

Актуальним питанням сьогодення залишається залучення учасників бойових дій, які отримали бойову травму до активного соціального, професійного та побутового життя в умовах мирного середовища після повернення додому. Нажаль, ми можемо констатувати, що система надання фізкультурно-спортивних послуг та проведення засобів комплексної фізкультурно-спортивної реабілітації в Україні лише формується, і зіштовхується 3 такими проблемами як: 1) недостатня кількість кваліфікованих фахівців, які мають бажання та вміють працювати із наслідками бойової травми; 2) відсутність матеріальнотехнічної бази та практична недоступність до неї у військовослужбовців із наслідками бойової травми; 3) юридичні, організаційно-комунікативні, 
морально-етичні проблеми; 4) прояви ПТСР, депресивних розладів, зменшений рівень стресостійкості та інші психо-фізичні розлади i дисфункції систем забезпечення життєдіяльності, зменшення рівня фізичної, психічної та соціальної адаптації, порушення соматичного здоров'я - це все спонукає до пошуку дієвих та ефективних форм та засобів впливу на організм військовослужбовців із наслідками бойової травми, які дозволять їм «повернутися з війни» на всіх рівнях здоров’я (фізичному, психічному та соціальному) [1].

О.В. Юденко у попередніх роботах здійснених щодо дослідження мотивації із застосуванням інноваційних форм i технологій: iз Є.В. Дьоміним, Р.П. Денисовим, Ю.М. Юденко та В.Ю. Кузьменко [1; 5] охарактеризовано структуру мотивації до фізкультурно-оздоровчих занять, зокрема спортивними іграми у осіб з інвалідністю на матеріалі баскетболу на візках; із О.М. Земечевим та I.I. Примою [2] вивчалась мотивація до занять східними єдиноборствами у осіб з порушенням слуху; із А.С. Білоус, О.П. Павленко та Є.В. Дьоміним [4] розглядалась структура мотивації осіб 3 травматичними ураженнями ОРА до спортивно-оздоровчої діяльності в пул-більярді. У дослідженнях проведених разом із А.А. Мартиросяном та А.С. Білоус [3] висвітлено аспекти застосування засобів регбі-7 як засобів фізкультурноспортивної реабілітації ветеранів АТО / ООС в Україні, а разом із І.В. Гевчуком, С.В. Бойченко та В.В. Шевченко [6] охарактеризовано особливості використання футболу як ефективного засобу фізкультурно-спортивної реабілітації учасників АТО / ООС в Україні.

В нашому дослідженні мотивації до занять у секціях з фізкультурноспортивної реабілітації (далі - ФСР) із використанням засобів спортивних ігор у військовослужбовців із дисфункціями внаслідок бойової травми (далі - БТ) за методикою В.І. Тропнікова $[1 ; 5]$ було залучено 42 чоловіка, які займаються регбі та 57 чоловіків, що займаються футболом. Методика дозволяє з'ясувати ступінь важливості причин (ситуацій, обставин), які спонукають військовослужбовців із наслідками БТ продовжувати займатися обраним адаптивним видом спорту. Дослідження здійснювалось нами протягом 2018-2020 pр.

На початку дослідження виявлено, що найбільш значущими мотивами для військових із наслідками БТ, які займаються адаптивним регбі виявилися потреби «фізичної досконалості» та «колективістської спрямованості»; бажання «поліпшити самопочуття та здоров'я» та потреба в «спілкуванні». Найменш значущими $є$ потреби «естетичного задоволення та гострих емоції», «схвалення» та отримання «матеріальних благ» (табл. 1). Серед учасників бойових дій, які займаються в секціях адаптивного футболу провідними мотивами та потребами, які спонукають їх до систематичних занять у секціях ФСР є мотиви ідентичні тим, які відзначено нами у військових із наслідками 
БТ, що займаються адаптивним регбі. Найменш значущими мотивами до занять у секціях ФСР на початку дослідження є аналогічні тим, що відзначено в групі військових-регбістів, із додаванням потреби у підвищенні престижу та бажанні слави.

Таблиця 1

\section{Середні показники мотивів, які спонукають військовослужбовців} із наслідками БТ до занять у секціях ФСР

(за B.I. Тропніковим; в балах)

\begin{tabular}{|c|c|c|c|c|c|}
\hline \multirow[b]{2}{*}{ № } & \multirow[b]{2}{*}{ Показник } & \multicolumn{2}{|c|}{ Етапи дослідження } & \multirow[b]{2}{*}{$\begin{array}{c}\mathbf{t} \\
\text { po3. }\end{array}$} & \multirow[b]{2}{*}{$\begin{array}{c}\mathbf{t} \\
\text { гр. }\end{array}$} \\
\hline & & $\begin{array}{c}\text { Початок } \\
(\mathbf{M} \pm \mathbf{m})\end{array}$ & $\begin{array}{r}\text { Кінець } \\
(\mathbf{M} \pm \mathbf{m}) \\
\end{array}$ & & \\
\hline \multicolumn{6}{|c|}{ Військовослужбовці, які займаються регбі $(\mathrm{N}=42)$} \\
\hline 1 & Пізнання & $26,02 \pm 1,48 \pm$ & $34,07 \pm 2,34$ & 18,84 & \multirow{11}{*}{1,99} \\
\hline 2 & Спілкування & $34,9 \pm 2,72$ & $38,66 \pm 3,09$ & 7,49 & \\
\hline 3 & Матеріальних благ & $14,75 \pm 1,83$ & $20,09 \pm 2,08$ & 12,49 & \\
\hline 4 & $\begin{array}{l}\text { Розвитку характеру і } \\
\text { психічних якостей }\end{array}$ & $27,57 \pm 1,04$ & $29,01 \pm 1,98$ & 4.17 & \\
\hline 5 & Фізичної досконалості & $30,92 \pm 1,71$ & $37,08 \pm 1,65$ & 18,35 & \\
\hline 6 & $\begin{array}{c}\text { Поліпшення самопочуття i } \\
\text { здоров'я }\end{array}$ & $33,21 \pm 1,09$ & $38,17 \pm 2,64$ & 11,25 & \\
\hline 7 & $\begin{array}{c}\text { Естетичного задоволення } \\
\text { та гострих емоцій }\end{array}$ & $10,01 \pm 1,12$ & $13,44 \pm 1,85$ & 10,28 & \\
\hline 8 & $\begin{array}{c}\text { Придбання корисних для } \\
\text { життя умінь і знань }\end{array}$ & $27,03 \pm 1,93$ & $29,43 \pm 1,22$ & 6,81 & \\
\hline 9 & Потреба у схваленні & $17,42 \pm 1,98$ & $23,55 \pm 1,88$ & 14,55 & \\
\hline 10 & $\begin{array}{c}\text { Підвищення престижу, } \\
\text { бажання слави }\end{array}$ & $19,66 \pm 1,27$ & $21,33 \pm 1,59$ & 5,32 & \\
\hline 11 & $\begin{array}{l}\text { Колективістська } \\
\text { спрямованість }\end{array}$ & $30,95 \pm 1,02$ & $35,29 \pm 1,78$ & 13,71 & \\
\hline \multicolumn{6}{|c|}{ Військовослужбовці, які займаються футболом $(\mathrm{N}=57)$} \\
\hline 1 & Пізнання & $25,07 \pm 0,98$ & $32,08 \pm 1,88$ & 24,96 & \multirow{11}{*}{1,98} \\
\hline 2 & Спілкування & $34,03 \pm 1,67$ & $37,56 \pm 2,47$ & 8,94 & \\
\hline 3 & Матеріальних благ & $15,07 \pm 2,22$ & $20,72 \pm 1,96$ & 14,40 & \\
\hline 4 & $\begin{array}{l}\text { Розвитку характеру і } \\
\text { психічних якостей }\end{array}$ & $27,99 \pm 1,93$ & $29,44 \pm 2,43$ & 3,53 & \\
\hline 5 & Фізичної досконалості & $30,32 \pm 1,45$ & $37,54 \pm 1,92$ & 22,66 & \\
\hline 6 & $\begin{array}{c}\text { Поліпшення самопочуття i } \\
\text { здоров'я }\end{array}$ & $34,71 \pm 1,45$ & $38,65 \pm 2,09$ & 11,69 & \\
\hline 7 & $\begin{array}{c}\text { Естетичного задоволення } \\
\text { та гострих емоцій }\end{array}$ & $11,09 \pm 2,22$ & $13,89 \pm 2,62$ & 6,16 & \\
\hline 8 & $\begin{array}{c}\text { Придбання корисних для } \\
\text { життя умінь і знань } \\
\end{array}$ & $27,33 \pm 1,88$ & $30,09 \pm 1,99$ & 7,61 & \\
\hline 9 & Потреба у схваленні & $17,11 \pm 1,44$ & $23,55 \pm 2,01$ & 19,66 & \\
\hline 10 & $\begin{array}{c}\text { Підвищення престижу, } \\
\text { бажання слави } \\
\end{array}$ & $19,88 \pm 1,03$ & $20,96 \pm 1,08$ & 5,46 & \\
\hline 11 & $\begin{array}{l}\text { Колективістська } \\
\text { спрямованість }\end{array}$ & $30,01 \pm 0,87$ & $34,56 \pm 1,09$ & 24,63 & \\
\hline
\end{tabular}


Проведений аналіз мотивів та потреб у військовослужбовців із наслідками БТ на кінець дослідження виявлено, що до занять у секціях ФСР із використанням засобів регбі виявили наступний розподіл провідних мотивів та потреб: потреби у спілкуванні, у поліпшення самопочуття і здоров'я, у фізичній досконалості; мотив та потреба пізнання (табл. 1). Серед учасників бойових дій, які займаються у секціях ФСР із використанням засобів футболу провідними мотивами $\epsilon$ аналогічні мотиви і потреби, як і в групі, що займається регбі, а також мотив колективістської спрямованості. Найменш значущими військовірегбісти назвали такі мотиви та потреби як: потреби в естетичному задоволенні та гострих відчуттях, в матеріальних благах та мотиви підвищення престижу і бажання слави. Для військовослужбовцівфутболістів із наслідками БТ мотив естетичного задоволення та гострих емоцій, потреба у матеріальних благах, мотив підвищення престижу та бажання слави.

Отримані дані на кінець дослідження мають достовірні відмінності за критерієм Стьюдента за всіма структурними мотиваційними компонентами в порівнянні із даними на початок педагогічного експерименту.

Частково поданий нами матеріал покладено співвиконавцем досліджень С.О. Шапіро в основу кваліфікаційної роботи «Фізкультурно-спортивні послуги - складова психо-фізичної та соціальної адаптації військових із наслідками бойової травми» на здобуття ступеня «магістр», яка захищена в 2020 р.

Висновки: проведений аналіз структури мотивації у військовослужбовців із наслідками БТ до занять у секціях ФСР за методикою B.I. Тропнікова засвідчив, що незалежно від етапу дослідження провідними мотивами $\epsilon$ потреби у спілкуванні, у поліпшення самопочуття і здоров'я, у фізичній досконалості; мотив та потреба пізнанні, при реалізації завдань ФСР додається мотив колективістської спрямованості.

\section{Література:}

1. Інноваційна технологія вивчення структури мотивації до фізкультурно-оздоровчих занять у осіб з інвалідністю (на матеріалі баскетболу). / О.В. Юденко, С.В. Дьомін, Р.П. Денисов, Ю.М. Юденко. Modern sience: problems and innovations: I Междунар. научнопрактическая конференция. 2020. С. 491-498.

2. Оцінка мотивації до занять східними єдиноборствами українських спортсменів 3 порушенням слуху 3 використанням інноваційних технологій. / О.В. Юденко, О.М. Земечев, І.І. Прима. 114 
«Спорт та сучасне суспільство» : Матер. ХІІІ Міжнар. студ. конф. [ «Студентська наука в сфері фізичної культури $і$ спорту: сучасні тренди», присвяч. 90-річчю НУФВСУ]. Київ: НУФВСУ. 2020. Част. І. C. $77-81$.

3. Про засоби фізкультурно-спортивної реабілітації ветеранів АТО/ООС в Україні (на матеріалі регбі-7). / О.В. Юденко, А.А. Мартиросян, А.С. Білоус Сучасні тендениії та перспективи розвитку фізичної підготовки та спорту Збройних Сил Украӥни, правоохоронних органів, рятувальних та інших спеціальних служб на шляху євроатлантичної інтеграції України: тези IV Міжнар. наук.-практ. конф. Київ : НОУО імені Івана Черняховського. 2020. С. 316-318.

4. Про інноваційні форми вивчення мотивації осіб з травматичними ураженнями опорно-рухового апарату до спортивно-оздоровчої діяльності в пул-більярді. / А.С. Білоус, О.П. Павленко, О.В. Юденко, Є.В. Дьомін. "Спорт та сучасне суспільство» : Матер. ХIII Міжнар. студ. конф. [«Студентська наука в сфері фізичної культури і спорту: сучасні тренди», присвяч. 90-річчю НУФВСУ]. Київ: НУФВСУ. Київ. 2020. C. 38-46.

5. Структура мотивації осіб 3 інвалідністю до фізкультурнооздоровчих занять спортивними іграми (на матеріалі баскетболу на візах). / О.В. Юденко, В.Ю. Кузьменко, Є.В. Дьомін, Ю.М. Юденко. Modern science: problems and innovations. Abstracts of the 4th International scientific and practical conference. SSPG Publish. Stockholm, Sweden. 2020. Pp. 266-271.

6. Футбол як ефективний засіб фізкультурно-оздоровчої реабілітації учасників військових локальних конфліктів. / І.В. Гевчук, О.В. Юденко, С.В. Бойченко, В.В. Шевченко. "Спорт та сучасне суспільство» : Матер. ХІІІ Міжнар. студ. конф. ["Студентська наука в сфері фізичної культури і спорту: сучасні тренди», присвяч. 90-річчю НУФВСУ]. Київ: НУФВСУ. Київ. 2020. С. 54-61. 